\title{
EDUCATION, LIFE CHANCES, AND THE COURTS: THE ROLE OF SOCIAL SCIENCE EVIDENCE
}

\author{
HENRY M. LEVIN* \\ INTRODUCTION
}

Public policy attempts to improve the "life chances" of youngsters from low income and minority backgrounds have focused primarily on the schools. "Life chances" is defined as a child's future ability as an adult to participate fully in the social, economic, and political life of society. More narrowly, "life chances" may be considered in terms of such outcomes as ultimate earnings, occupational status, and political efficacy. The crucial role of the school in preparing students for these eventualities has been tacitly assumed. It is no surprise, therefore, that in their quest for greater equality among persons of different races and social class origins, both policy makers and the courts have devoted extensive efforts in an attempt to alter the organization and financing of education. ${ }^{1}$

There are three principal areas of reform to which policy makers and the courts have directed themselves in the last two decades: school desegregation, the provision of additional resources for the education of children from low income families, and reform of state educational finance systems by reducing the reliance upon local property wealth as the determinant of local school expenditures. ${ }^{2}$ Each of these reform measures comports with notions of basic fairness and, indeed, could be defended on these grounds alone. But this view of reforms-that they are essential in a "just" society-has been overshadowed by the claim that social science research has shown that the particular educational strategies offered to the courts enhance the life chances of children. Educational reform litigation increasingly relies on social science evidence, as seen in the challenges to school segregation, to the present methods of financing education, and to student classification policies. ${ }^{3}$

This article explores the appropriateness of using social science evidence as a basis for formulating public policy and for deciding law suits in these particu-

\footnotetext{
* Professor, School of Education and Department of Economics, Stanford University.

1. See generally D. Kirp \& M. Yudof, Educational Policy and the Law chs. 4, 6, \& 7 (1974).

2. A recent summary of these strategies is contained in Staff of Senate Select Comm. on Equal Educ. Opportunity, 92d Cong., 2d Sess., Report: Toward Equal Educational. Opportunity (Comm. Print 1972). See also J. Coons, W. Clune III, \& S. Sugarman, Private. Wealth and Public Education (1970); J. Owen, School Inequality and the Welfare State (1974); Wise, School Desegregation: The Court, the Congress, and the President, 82 SCHOoL Rev. 159 (1974).

3. D. KIRP \& M. Yudof, supra note 1.
} 
lar areas. In the course of this exploration, four questions have to be addressed: (1) To what degree can social science methodology determine the impact of schooling on such life chance outcomes as income and occupational attainment, separating out other factors influencing life chances such as family background and IQ? (2) To the extent that social science research presents conflicting theories of these relationships, why do some theories receive considerable attention in the policy arena while others do not? (3) What impact does social science evidence have on the evolution of law and public policy with respect to education? (4) Finally, what contribution can the social sciences make to the issues raised in litigation?

\section{Effects of Education on Life Chances}

How might the social scientist attempt to trace the effects of a particular educational strategy on the life chances of an individual or group of persons? The difficulties inherent in this task can be illustrated by considering the fundamental characteristics of the problem. At the outset, there is a complex multitude of psychological, social, genetic, political, economic, and educational influences that can determine occupational attainments and earnings. The actual effect of education and of a particular educational environment is particularly difficult to trace because the outcomes that we wish to review are very much removed in both time and context from the schooling process. Typically, research in this area is intended to relate the income and occupation of an individual or a group of persons to the schooling which they received many years before and under circumstances very different from their present situations. Also, the educational experiences of an individual are so closely tied to his social class origin and family experiences that it is virtually impossible to isolate the distinct influences of each on life chances.

In addressing this issue, social scientists have two basic approaches at their disposal. ${ }^{4}$ The first is the purely experimental approach. In theory, an experiment would select persons who were similar in every respect and assign them to a different quantity and quality of education, and then monitor them over their life-times in order to determine how the differences in educational experiences are translated into differences in life-time experience. Such an experiment would probably require a minimum of thirty years and would have to ensure

4. For the best discussion of the experimental and quasi-experimental approaches in a related context see D. Campbell \& J. Stanley, Expermental, and Quasi-Experimental Desicis for RESEARCH (1966). For a more skeptical statement on the ability of social science research to provide "proof" for a theory sec Address by D. Campbell, betore the Society for the Psychological Study of Social lssues meeting with the American Psychological Association. New (H)ans. La. Sopt. 1. 1974

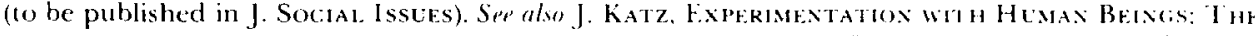

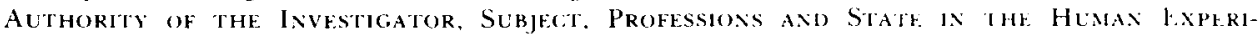
mentation Process (1972). 
that the individuals in both the experimental and control groups were treated identically in their pre-adult years, with the exception of schooling. In other words, such factors as genetic background, family environment, community factors, medical care, nutrition, friendships, and so on, would have to be identical in order to draw an accurate inference about the effects of differences in schooling.

For obvious reasons, however, such an exercise is impossible. Not only do we lack the luxury of several decades or a life-time to carry out research for impending policy decisions, but the conditions that we would have to place on the human subjects in order to conduct the experiment could very well raise questions about a violation of their constitutional rights. ${ }^{5}$ Even were such an experiment feasible, we would not be able to generalize beyond the actual educational strategies that were utilized and the specific persons or groups of persons that were involved in the experiment. Since there are infinite combinations of both, even a relatively large scale experiment would reveal information about only a limited range of alternatives and population groups. Moreover, in a society such as ours, the relationship of education to one's life chances is likely to change from generation to generation, meaning that the results obtained from a particular experiment might not be applicable to conditions some forty years later when the experiment was finally completed.

Thus, the most powerful investigative tool that science has to offer for an understanding of the relationship between education and life chances is politically and practically infeasible. At best, experimentation can be used to test minor hypotheses that may be related to some later outcome. ${ }^{6}$ For example, it may be possible to set up an experiment to determine the effect of teachers' attitudes on student achievement or educational aspirations, assigning students randomly to two different types of teachers, and holding other factors constant for the period of the experiment. Outcomes would be measured by standardized test scores and such elements of educational aspiration as incentive for further schooling. Even with this more limited type of experiment, it is a formidable endeavor to fulfill the ceteris paribus conditions. And even more problematical is the relationship of the experimental outcomes to life success. One would have to make the assumption that student test scores and attitudes

5. It is very difficult to explain the experimentation in such precise terms that a layman will understand the full implications of the testing and thus be able to provide an effective waiver. Compare the requisite standards for valid consent in the area of medical experimentation and research. See Kaimowitz v. Department of Mental Healıh, Civil No. 73-19 434-AW (Mich. Cir. Ci., July 10. 1973) for a judicial response to the legal and medical issues posed by experimental psychosurgery. In that case, the coun determined that the consent must be competent, voluntary, and knowledgeable. Id. at 31-32. Sur also Herch \& Flower, Medical and Psychological Experimentation on California Prisoners. 7 U. Cal. Davis L. Rev. 351 (1974).

6. A creative attempt at using experimental methodology to ascertain the effects of intervention on racial interactions is found in Cohen \& Roper, Modification of Interacial Interactions Disability: An Application of Status Characteristic Theory. 37 Am. Sociological Rev. 643 (1972). 
are related initially to educational attainment, and ultimately to income and occupational attainment. While the logic of such a relationship may be compelling, any conclusion in this respect is beyond what could be substantiated by results from the experiment just outlined.

An alternative social science strategy that is used when direct experimental research is not feasible is the quasi-experimental approach. ${ }^{7}$ This latter strategy represents an attempt to parallel the experimental conditions by using statistical procedures to "correct" for those factors that cannot be controlled experimentally. Sometimes the quasi-experimental approach is termed a "natural" experiment because data are collected from an actual life situation rather than an experimental one. For instance, a researcher who is interested in the effects of schools on life chances might collect historical data for a sample of adult males or females. These data would include the present earnings and occupation of the individuals, information on their parents' class origins, characteristics of the schools that they attended, information on their friends, their work experience, and so on. A statistical model would then be constructed in an attempt to determine the relationship between the educational variables and the occupational and income attainments of the sample being studied.

Quasi-experimental studies attempt statistically to relate all relevant factors that might explain a particular phenomenon. The success of such an approach is dependent upon the ability to identify and measure these factors and to relate them in the statistical analysis in a manner reflecting the true phenomenon. As mentioned previously, however, there are an unlimited number of potential influences on adult outcomes and there are a variety of plausible ways that each can be measured and related to other variables in the analysis. In an area where choices must be made among the myriad of possible variables, measures, and relationships, the complexity and arduous nature of this type of statistical analysis necessarily limits the researcher to a narrow set of alternative formulations. The actual choice of factors to be included in a study, the measures of those that are ultimately selected, and the structure used to relate them is in part determined by the personal predilections of the researcher. ${ }^{8}$

In summary, there are enormous difficulties in determining how a host of genetic, psychological, social, cultural, political, economic, educational, and chance factors determine a person's ultimate life attainments. These difficulties and the complex nature of the problem suggest the inability of social science research to derive answers that can be utilized with any reasonable degree of reliability. Indeed, it is little wonder that opinions on the subject differ as much among social scientists as they do among laymen. Because of the inherent inadequacy of our present tools, there is no social science concensus on the

7. See D. Campbell \& J. Stanley, supra note 4.

8. See generally Levin, The Social Science Objectivity Gap, 55 Saturday Rev. no. 46, at 49 (1972). 
appropriate educational strategies for improving the life chances of children from low income and minority backgrounds. ${ }^{9}$

\section{Hypotheses About Schooling and Adult Attainments}

The fact that social science has not provided a definitive or even a tentatively acceptable analysis of the relation between schooling and adult attainments does not mean that there exist no hypotheses on the subject. To the contrary, there are at least four such theories relating schooling to eventual adult occupation and income. Each of them presumes a relatively different educational approach toward improving the life chances of disadvantaged students.

\section{A. Skills or Cognitive Achievement}

Much of the literature on schooling and adult income is dominated by the notion that education produces verbal and mathematical skills as well as other knowledge that translate into higher productivity in the market place and consequently higher earnings. Under this hypothesis, the more cognitive knowledge that children acquire in school, the greater will be their life attainments. Accordingly, the effect of schooling or income is determined by the effect that schooling has on skills and knowledge. Those schools that contributed toward greater gains on achievement tests ostensibly would have the greatest impact on improving the future adult attainments of their pupils. Hence, the appropriate educational strategies would be those that are consistent with increasing the test scores of children from low income backgrounds. The most notable of these approaches is the provision of additional educational resources as exemplified by programs of compensatory education in the elementary and secondary schools ${ }^{10}$ and such pre-school programs as Project Head Start. ${ }^{11}$ It has also been argued that greater social class and racial integration of schools will have this effect. ${ }^{12}$

9. See Address by D. Campbell, supra note 4 .

10. In addition to programs under Title $I$ of the Elementary and Secondary Education Act, 20 U.S.C. $\$ 241$ (1970), several states provide funds for compensatory programs. See, e.g., Cal. Educ. CODE $\$ \$ 6499.230-6499.238$ (West 1975); WIS. STAT. ANw. $\$ \$ 115.90-115.94$ (Supp. 1974).

11. Project Head Start, instituted under authority of Title II of the Economic Opportunity Act of 1964, 78 Stat. 516 (1964), as amended 42 U.S.C. $\$ 2781$ (1970), offers a variety of health, social and educational services to enable pre-school children from deprived families to enter kindergarten or first grade.

12. See Coleman. Toward Open Schools. 9 Pub. INTerrst 20 (Fall 1967). 


\section{B. Noncognitive Characteristics for Work Relations}

In contrast to the cognitive achievement hypothesis outlined above, the second thesis views the school as inculcating students with the appropriate behaviors for occupying particular positions in the occupational or organizational hierarchy. Such characteristics as respect for rules, dependability, and internalization of the norms of the workplace have been found to be strong predictors of employee ratings by supervisors and of income levels. ${ }^{13}$ The workplace is seen as a hierarchically differentiated organization in which different positions require varying worker characteristics: ${ }^{14}$

those at the base of the hierarchy requiring a heavy emphasis on obedience and rules and those at the top, where the discretionary scope is considerable, requiring a greater ability to make decisions on the basis of well-internalized norms. This pattern is closely replicated in the social relations of schooling. Note the wide range of choice over curriculum, life style, and allocation of time afforded to college students, compared with the obedience and respect for authority expected in high school.

According to the second hypothesis, while minimal skills are necessary for productivity, most of the discrepancy in occupational attainment and earnings is attributable to noncognitive work traits. Four of these work prerequisites - proper level of subordination, discipline, supremacy of cognitive over affective modes of response, and motivation according to external reward structures-have been identified. ${ }^{15}$ Also identified are the ways in which the schools are structured to foster these traits. For example, subordination and proper orientation to authority along hierarchical lines are necessary in virtually all modern work enterprises. Thus, "[a]s the worker relinquishes control over his activities on the job, so the student is first forced to accept, and later comes personally to terms with, his loss of autonomy and initiative to a teacher who acts as a superior authority, dispensing rewards and penalities." 16 Similarly, it is argued that other school practices are related to the requirements of the workplace; students from lower social class origins are being prepared to occupy lower status occupations and those from higher class backgrounds are being socialized to undertake professional and managerial roles.

This hypothesis suggests that the contribution of schooling should be evaluated in terms of its impact on creating productive worker characteristics. Unfortunately, the work hierarchy is so unequal in terms of job requirements, satisfaction, income, and prestige that providing everyone with the "most productive" traits is not likely to increase life chances for everyone. Rather, it

13. See R. Edwards, Alienation and Inequality: Capialist Relations of Production in a Bureaucratic Enterprise, July 1972 (unpublished Ph.D. thesis. Department of Econonics. Harvard Lniversity).

14. Bowles. Understanding Unequal Economic Opportunity. 63 Aw. Ecox. Rev. 346.353 (1973).

15. Gintis. Education, Technology and the Characteristics of Worker Productivity in Procedings of the Eighty-Fourth Annual Meeting. 61 Aw. Ecos. Rev. 266 (1971) [hereinafier cited as Gintis].

16. Id. at 274 . 
would simply redistribute opportunities among the population with some individuals improving their standing and others losing ground in terms of productive adult roles. In contrast with the thesis that everyone's productivity is enhanced by the attainment of greater cognitive skills, it is difficult to argue that productivity for all individuals would rise with the inculcation of higher echelon occupational traits, so long as the number of such positions is rationed by the occupational pyramid. In short, the view that the schools affect the life chances of students by preparing them for particular levels of the work hierarchy suggests that schools perform their function when they differentiate and produce the highly unequal outcomes that correspond to adult roles. ${ }^{17}$ The most that could be accomplished by the schools in such a world is that students from disadvantaged backgrounds would have the same chance to be prepared for particular roles as those from advantaged backgrounds, in contrast with the present system which relegates racial minorities and the children of the lower class to corresponding lower class adult roles.

\section{Screening and Certification}

The third major hypothesis of how education affects earnings and occupational status views the school as an organization whose principal function is to sort and select students. According to this interpretation, the schools carry out a sophisticated process of assessing the cognitive and personal attributes of a student and then assigning him to a particular educational fate. Through testing, ability grouping and tracking, curriculum assignment, grading systems, and stratification by social class among neighborhoods, the schools act as an enormous filter. ${ }^{18}$ Students who have the low-level skills and personality characteristics suitable for the lower end of the work hierarchy are placed in slow ability tracks or in inner-city schools that provide them with little incentive for further schooling. In contrast, students with high test scores and with personality attributes that correspond with the upper level of the job hierarchy are encouraged to pursue further education and will be rewarded with the high grades which represent the admission requirement for obtaining superior educational credentials.

The screening and certification hypothesis assumes that the occupational and income attainment process for an individual is determined largely by the amount of schooling he has received, his field of study, and the prestige of the institutions that he attended. ${ }^{19}$ Thus, the sorting and selection of each stu-

17. See Levin, A Conceptual Framework for Accountability in Education, 82 School Rev. 363 (1974).

18. See I. Berg, Education and Jobs: The Great Training Robbery (1970); Hall, On the Road to Educational Failure: A Lawyer's Guide to Tracking, 12 INEquALTY IN ED. 1 (1970); Kirp, Schools as Sorters: The Constitutional and Policy Implications of Student Classification, 121 U. PA. L. REv. 705 (1973); Sorgen, Testing and Tracking in Public Schools, 24 Hastings L.J. 1129 (1973). Use of the term "filter" is adopted from Arrow, Higher Education as a Filter, 2 J. Pub. Econ. 193 (1973).

19. See generally Bowles, Unequal Education and the Reproduction of the Social Division of Labor, in 
dent according to his initial and developing characteristics are identified in the job market by an educational credential which is used to establish his place in the occupational structure. Since such credentials are awarded on the basis of "productive" characteristics, employers need only to find out which "certificate" an individual possesses in order to judge his suitability for a particular position. ${ }^{20}$ The hypothesis thus suggests that schools do not serve to educate students but instead to select them for their future fates according to characteristics derived from their genetic heritage and non-school environments. It has been further argued that the traits used for selection have little to do with real productivity differences and that persons with higher educational credentials are simply placed in jobs that are ostensibly more productive because of such factors as, for example, greater capital investment per worker. ${ }^{21}$

Presumably, then, the reason that children from lower income and minority backgrounds do more poorly in both schools and later careers is that they are filtered out rather early on the basis of low initial test scores and personality traits deemed inappropriate for further educational selection. Their low educational credentials mean that they will occupy low productivity jobs with little hope of access to the more productive and remunerative ones. ${ }^{22}$ The educational policy implications of this hypothesis are not unlike those of the second hypothesis discussed earlier, which is concerned with the noncognitive characteristics or behavior appropriate at various levels. In both instances, the schools tend to reinforce the initial attributes of students; according to the third hypothesis, through selection and certification procedures, and according to the second hypothesis, through selection, differentiated preparation by category of student (especially social class), and certification. The major distinction between the two views of the educational process is that the sorting hypothesis assumes that the school has no educational effect on the student and that the observed differences merely reflect variation in natural endowments and outof-school influences. The noncognitive socialization theory, on the other hand, assumes that schools do have an effect-that of further reinforcing these initial differences.

Only by eliminating all sorting and selection based on characteristics that coincide solely with race and social class will educational credentials be distributed in a more nearly random manner. Yet, since grades and examination scores are based substantially upon behavior and language styles which in turn are heavily determined by racial and social class backgrounds, drastically dif-

Schooling in a Corporate Society 36 (M. Carnoy ed. 1972); Karabel, Community Colleges and Social Stratification, 42 HARv. Ed. Rev. 521 (1972).

20. See Arrow, supra note 18; Spence, Job Market Signaling, 87 Q.J. Econ. 355 (1973).

21. See Thurow, Education and Economic Equality, 28 Pub. Interest 66 (Summer 1972); I. BerG, supra note 18.

22. See D. Gordon, Theories of Poverty and Underemployment (1972). See also Harrison, Education and Underemployment in the Urban Ghetto, 62 Aм. EcoN. Rev. 796 (1972). 
ferent criteria would have to be developed for determining a student's educational success.

\section{Reduction of Social Class and Racial Frictions}

The final hypothesis considers the attitudes of all students towards racial and social class differences. The premise is that the better all racial and social class groups understand each other, and the greater the number of intergroup contacts, friendships and interactions, the less racial and class conflicts there will be in adult life. ${ }^{23}$ The role of the school in this regard is crucial, for racial, cultural, and social class diversity in the educational environment is considered to be a prerequisite to greater justice in the distribution of jobs and earnings among the population. It is assumed that such a policy would have a marked impact on reducing labor market discrimination against racial minorities and members of the lower classes.

The obvious educational strategies that are consistent with this hypothesis are those which lie at the heart of the school desegregation movement. These include greater social class and racial heterogeneity among students and the introduction of a more multi-culturally oriented curriculum. The former action would be accomplished through massive desegregation of schools, thereby increasing the diversity of student populations and of the resultant educational and social interactions. The latter approach, which emphasizes a greater balance among the cultural contributions of different social and racial groups, would be implemented through changes in instructional materials, teacher training, and teacher selection.

\section{EMPIRICAL SUPPORT FOR THE HyPOTHESES}

According to the conventional image of science, mere application of research methodology to competing hypotheses will reveal which one best describes the world. Thus, through the use of sophisticated empirical research techniques we should be able to distinguish among those approaches worthy of elevation to the level of explanatory theory and those which should be banished

23. Contacts that bring knowledge and acquaintance are likely to engender sounder beliefs about minority groups .... Prejudice ... may be removed by equal status contact between majority and minority groups in the pursuit of common goals. The effect is greatly enhanced if this contact is sanctioned by institutional supports (i.e., by law, custom, or local atmosphere), and if it is of a sort that leads to the perception of common interests and common humanity between members of the two groups.

G. Allport, The Nature of Prejudice 268, 281 (1954); see M. Deutsch \& M. Collins, Interracial Housing: A Psychological Evaluation of a Social Experiment (1951); J. Dollard, Caste and Class in a Southern Town (1937); G. Myrdal, An American Dilemma (1944). But see Armor, The Evidence on Busing, 28 PuB. INTERest 90, 102-05 (Summer 1972); Armor, The Double Double Standard: A Reply, 30 Pub. Interest 119, 127-29 (Winter 1973). 
as falsehood. But, as noted previously, the tools of social science are inadequate for this task. The social science evidence that does exist is incomplete, fragmented, and applicable to narrow populations only. It cannot, therefore, be conclusive. $^{24}$

Although each hypothesis can be shown as consistent with some observable facts, the same facts often lend support to more than one of the hypotheses. Table I represents a summary of the evidence in support of the four hypotheses linking education with the life chances of poor and minority students. The educational strategies and the measures of educational outcome that are consistent with each hypothesis are shown in this table. But beyond this, the important concern is whether certain specified educational outcomes have been produced successfully by the corresponding educational strategy. The extent to which the desired educational outcome is linked to such adult attainments as income and occupational status is of substantial concern as well. These aspects are essential to determining the degree to which we can expect a particular educational strategy to produce enhanced income and occupational positions. Accordingly, the summary of the evidence linking the educational strategy to a specified educational output, and the educational output to measures of life attainment is also provided in Table I. It is important to observe that a lack of evidence for the impact of any particular strategy does not mean that the approach is without merit. It simply means that existing research-which may be quite minimal on the subject-has not provided sufficient empirical support for such a strategy.

\section{A. Measures of Educational Outcome}

The cognitive skills hypothesis has as its measure of educational outcome standardized test scores. Despite the fact that there are many and diverse measures of the broad range of cognitive skills, the evidence, as indicated below, is remarkably consistent whether IQ tests, achievement tests, reading tests, mathematics tests, or others are used. In order to raise the level of cognitive performance of low income and minority youngsters, the educational strategies usually invoked are the provision of greater resources for compensatory education and racial and socioeconomic integration. The evidence is weak that either of these policies has significant impact on test scores. For example, neither the Coleman Report ${ }^{25}$ nor subsequent studies, some of which used the data collected for the Coleman Report, found that differences in the level of educational resources have any major impact on test scores. ${ }^{26}$ An analysis based on the statistical results of a number of these studies has shown that even major increases of those educational resources most related to test

24. See Address of D. Campbell, supra note 4

25. J. Coleman, Equality of Education Opportunity (1966).

26. See, e.g., C. Jencks, INequality 93-95, 255 (1972) [hereinafter cited as Jencks]. 


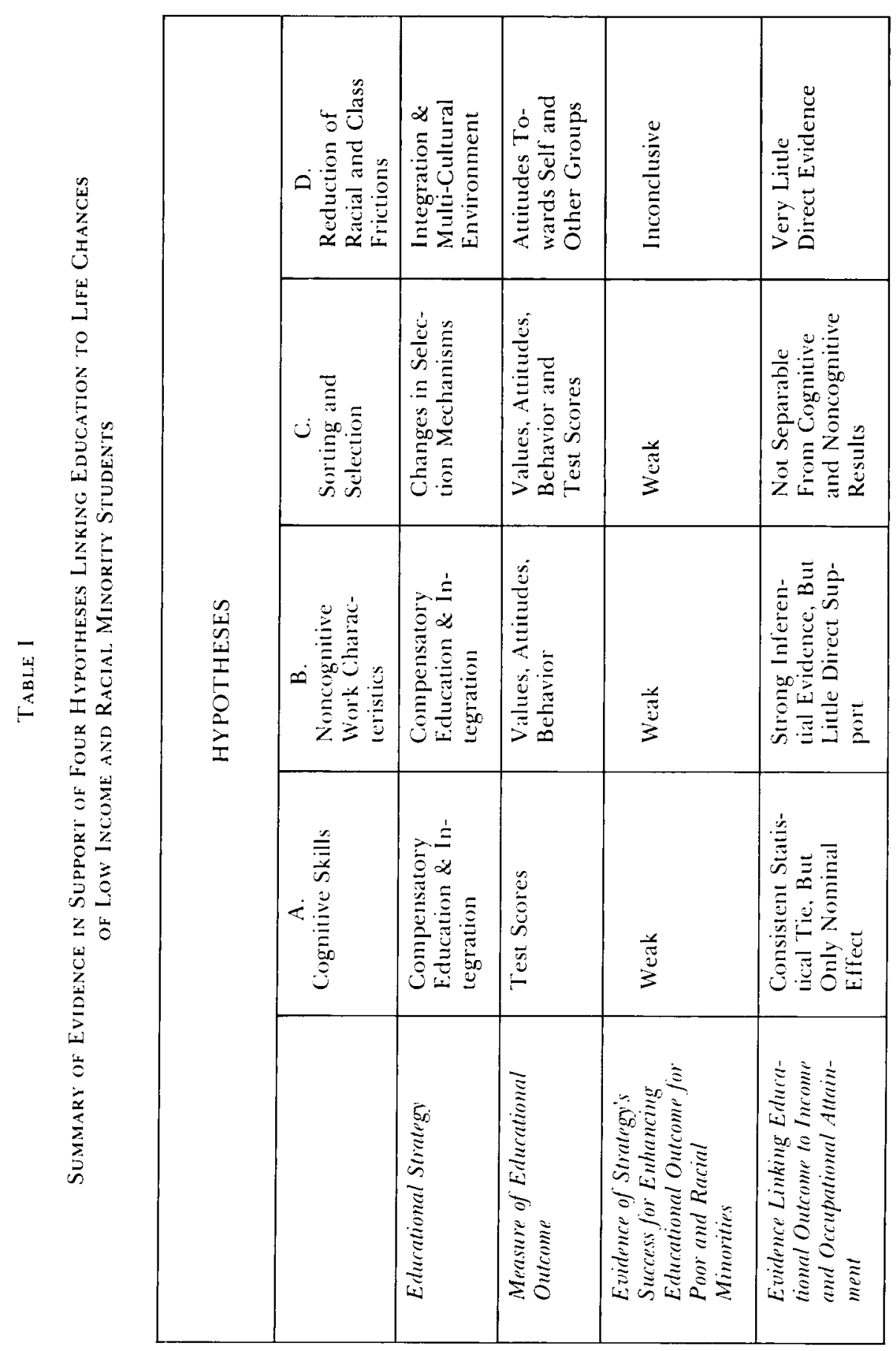


scores would not come close to eliminating the performance gap between white and black students. ${ }^{27}$ Evaluations of compensatory education programs carried out under Title I of the Elementary and Secondary Education Act of $1965^{28}$ similarly have been unable to demonstrate any significant relationship between increased resources and improved test scores. ${ }^{29}$

While some studies have suggested that both socioeconomic and racial integration improve the test scores of minority and low-income students, ${ }^{30}$ these conclusions have been contested in other evaluations. ${ }^{31}$ Thus, neither compensatory education strategies nor those related to desegregation show anything other than a weak relationship to cognitive gains. Even when statistical differences in favor of these strategies are reported, the improvement in cognitive skills is generally marginal.

Assuming that strategies other than compensatory education and racial and class integration could be found which did improve cognitive scores substantially, what would be the impact of such an improvement on income and occupational attainments of poor and minority youngsters? Numerous studies demonstrate a consistent statistical relationship between test scores and these measures of life success. ${ }^{32}$ The explanatory significance of this relationship is

27. Carnoy, Is Compensatory Education Possible?, in Schooling in a Corporate Societr 175 (M. Carnoy ed. 1972).

28. 20 U.S.C. $\$ 241(1970)$.

29. See, e.g., M. Wargo, G. Tallmadge, D. Michaels, D. Lipe, \& S. Morris, ESEA Title I: A Reanalysis and Synthesis of Evaluation Data From Fiscal Year 1965 Through 1970, March 1972 (unpublished document on file at American Institute for Research, Palo Alto, Cal.); Levin, Effects of Expenditure Increases on Educational Resource Allocation and Effectiveness, in School. FinANCE IN Transirion 177 (J. Pincus ed. 1974). A study prepared by the Rand Corporation acknowledges that "[v]irtually without exception, all of the large surveys of the large national compensatory education programs have shown no beneficial results on average." THE RAND Corporation, How Effective is Schooling? 124-25 (1971). The study, however, is quick to note that "the evaluation reports on which the surveys are based are often poor and research designs suspect." Id. at 125. The caveat points to such factors as non-random assignment of children, bias in project selection, "continuation" of the questionable evaluation procedures. Id. at 106-07. Consequently, "no... assurance is possible.. that the survey evaluations used in arriving at such a verdict were themselves an accurate description of the real world. . ."Id. at 105.

30. See J. Coleman, supra note 25; U.S. Commission ON Civil Rights. Racial Isolation in the Public Schools (1967); Pettigrew, Useem, Normand, \& Smith, Busing: $A$ Review' of "The Evidence," 30 Pub. Interest 88 (Winter 1973).

31. See Armor, The Evidence on Busing, 28 PuB. INTEREST 90 (Summer 1972); Bowles \& Levin, The Determinants of Scholastic Achievement-A Critical Appraisal of Some Recent Evidence. 3 J. HuMAN Resources 3 (1968); Cohen, Pettigrew, \& Riley, Race and the Outcomes of Schooling, in ON EQUaLtTY of Enucational Opportunity 343 (F. Mosteller \& D. Moynihan eds. 1972); Hanushek \& Kain, On the Value of Equality of Educational Opportunity as a Guide to Public Policy. in id. at 116; St. John, Desegregation and Minority Group Performance, 40 REv. ED. RESEARCH 111 (1970); Smith, Equality of Educational Opportunity: The Basic Findings Reconsidered, in ON EQUaLITY of EDUCATIONAL OPPORTUNITY, supra at 230.

32. See, e.g., D. Duncan, D. Featherman, \& B. Duncan, Socioeconomic Background and Achievement (1972); Jencks; T. Ribich \& J. Murphy, The Economic Returns to Increased Educational Spending, 1974 (to be published in J. Humax Resources); P. Wachtel. The Effect of School Quality on Achievement, Attainment Levels and Lifetime Earnings, May 1974 (unpublished paper at the New York University Graduate School of Business Administration); Griliches \& Mason. 
nonetheless quite weak. ${ }^{33}$ At most only about 10 per cent of the differences in income can be explained by test scores, leaving 90 per cent or more to be explained by other factors. Furthermore, relatively large increases in test scores are associated with only modest increases in income. While the apparent effect of test scores on occupational status is somewhat higher, it still only explains-at the most-about 25 per cent of the variance. ${ }^{34}$ Differences in test scores, therefore, are not a major factor in explaining why occupational attainments and incomes differ among various cross sections of the population. In summation, the hypothesis that improving the cognitive test scores will raise the adult attainments of children from low income and minority families shows little promise of success because (1) available educational strategies have not demonstrated much success in improving test scores of these students and (2) increases in test scores show only modest effects on adult income and occupations.

\section{B. Evidence on Noncognitive Work Characteristics}

In contrast with the numerous studies exploring the relationship between test scores and increased resources or integration, there are few research studies devoted to the other hypotheses. Nonetheless, there have been some attempts to explore the noncognitive worker characteristics thesis. As indicated previously, the measure of educational outcome relating such traits to income and occupation are those values, attitudes, and behaviors which are required for work positions in a hierarchical setting. These include such characteristics as dependability, subordination to authority, respect for rules, and internalization of work norms. ${ }^{35}$ Measures of noncognitive work traits have been demonstrated to be related to grades awarded by teachers, more so than are test scores. ${ }^{36}$ However, there is apparently no study which has attempted to determine the degree to which the worker characteristics of poor and minority students can be altered by compensatory education or integration. Contrariwise, there is a strong presumption that the present approach will resist change because it is functional to the reproduction of the capitalist work hierarchy. ${ }^{37}$ Accordingly, the relationship between the educational strategy and the desired educational outcomes must be considered as weak.

Education, Income, and Ability, $80 \mathrm{~J}$. PoL. ECon. 574 (1972); Sewell \& Hauser, Causes and Consequences of Higher Education: Models of the Status Attainment Process, 54 AM. J. Agric. Econ. 851 (1972); Taubman \& Wales, Higher Education, Menial Ability, and Screening, 81 J. Pol. Econ. 28 (1973).

33. See Bowles \& Nelson, The Inheritance of IQ and the Intergenerational Reproduction of Economic Inequality, 56 Rev. Econ. \& Statistics 39 (1974).

34. See generally O. Duncan, D. Featherman, \& B. Duncan, supra note 32; Jencks; Bowles \& Nelson, supra note 33; Griliches \& Mason, supra note 32; Sewell \& Hauser, supra note 32

35. See, e.g., R. Edwards, supra note 13; Bowles, supra note 14; Bowles \& Gintis, IQ in the U.S. Class Siructure, 3 Social Policy 65 (Nov./Dec. 1972, Jan./Feb. 1973); Gintis.

36. See Gintis.

37. See Bowles, supra note 14; Bowles, supra note 19. 
There is, however, evidence linking noncognitive outcomes to income and occupational attainments. The amount of schooling a person receives is a more powerful determinant of income and occupation than are test scores. For example, three studies using longitudinal data-permitting prior schooling experiences and test scores to be linked to earnings-have found either a nonexistent or a relatively negligible correlation between test scores and earnings. This is in contrast to the rather pronounced impact that the amount of schooling has on ultimate income. ${ }^{38}$ Thus it appears that the amount of schooling a person receives has a considerable effect on adult success, independent of the cognitive skills attained from the educational process.

But there is additional evidence supporting the noncognitive work characteristics hypothesis: teachers tend to award higher grades to students who exhibit personality characteristics functional in the work hierarchy. ${ }^{39}$ One study of a sample of workers from three different enterprises found that these personality traits or characteristics are related both to supervisors' ratings and to earnings, even after differences in cognitive skills among employees is accounted for. ${ }^{40}$ Obviously, much more research is needed in this area, but the view that noncognitive educational outcomes have more important influences on life attainments than cognitive ones has considerable support. Nevertheless, the lack of evidence indicating that educational strategies can alter the distribution of these traits suggests that the policy implications of this hypothesis are minimal.

\section{Evidence on Sorting and Selection}

The difficulty in evaluating the sorting and selection hypothesis is that there is virtually no reliable way to distinguish its effects from those generated by the cognitive and noncognitive socialization hypotheses. Essentially, the difference between the sorting and selection hypothesis and the other two is that the former assumes that schools do not produce the cognitive and noncognitive traits that are reflected in educational attainments and credentials. Rather, schools simply identify and select students according to those traits which they already possessed or acquired outside of the school setting, and bestow upon them differing educational rewards. Whether schools sort according to already-existing characteristics or actually inculcate these characteristics in students cannot be determined without very intensive studies. Possibly both aspects are prevalent but there is no apparent evidence that permits differentia-

38. See T. Ribich \& J. Murphy, supra note 32; P. Wachtel, supra note 32; Sewell \& Hauser. supra note 32. Even when test scores are included in the analysis, the effect of schooling alonc on earnings is not significantly reduced. Set Bowles. supro note 14; Gintis; Griliches \& Mason, supra note 32 .

39. See Gintis

40. See R. Edwards, supra note 13 . 
tion between the two. ${ }^{41}$ Thus, any evidence tending to support the cognitive and noncognitive socialization hypotheses would certainly be consistent with a sorting and selection hypothesis as well.

\section{Evidence on Reduction of Frictions Between Races and Classes}

Finally, the hypothesis on reducing racial and social class frictions measures educational outcome by the attitudes of representatives of each group towards themselves (self-image and sense of efficacy), as well as by attitudes that connote an understanding and acceptance of members of other groups. Whether the educational strategies of desegregation and multi-cultural emphasis ${ }^{42}$ have long-run effects on attitudes and behavior is questionable. That the evidence in these areas is both controversial and contradictory is reflected in recent debates on the subject. ${ }^{43}$ In some instances desegregation of the schools appears to have improved the self-images of racial minorities and racial attitudes of both majority and minority students; ${ }^{44}$ in other cases there seem to have been no effects, or even negative ones. ${ }^{45}$ One of the basic problems that pervades this research is the questionable reliability and stability of any measure of human attitudes. Given the variable quality of desegregation efforts and multi-cultural educational programs, it is not surprising to find such a divergence of results.

There is at least some empirical evidence supporting the view that socioeconomic integration improves the life chances of low status children. An analysis of data collected for a sample of youngsters then in the ninth grade, supplemented by follow-up information on their subsequent schooling, occupational attainments, and income nine years later, indicates that students who had similar test scores and social class backgrounds as well as educational attainments had higher incomes if they had attended secondary schools with other students from high socioeconomic backgrounds. ${ }^{46}$ A particularly interesting aspect of this study was that low status individuals appeared to "gain" more than twice as much income from this effect as did the high status individuals. However, even this finding applies only to the young adults in this particular

41. A related question is the degree to which educational credentials reflect differences in productivity as opposed of their role in screcuing employees for particular ocupational positions without regand for productivis. Compare Taubman \& Wales, supra note 32, with Layard \& Psacharopoulos. The Soreening Hypothesis and the Ratums to Education. 82 J. Pol. Ecox. 985 (1974).

42. See uxt at p. 226 supra.

43. See Armor, supra note 31: Armor. supra note 23; Pettigrew. Useem, Normand, \& Smith. supra note 30.

44. Sep G. Allaport, supra note 23; M. Deutscin \& M. Collins, supra note 23; J. Dollard, supra note 23; G. MYrDal. supra note 23. See also Epps, The Impact of School Desegregation on Aspirations. Sulf-Concepts and Other Aspects of Personality. 39 Law \& Coxtemp. Prob. no. 2. at 300 (1975) for a review of the rescarch on the impact of desegregation on self-esteem, and Cohen. The Effects of Desegregation on Race Relations, 39 Law \& Contemp. Prob. no. 2. at 271 (1975) for a review of the research on the impact of desegregation on interracial relations.

45. See Armor, supra note 23.

46. See T. Ribich \& J. Murphy, supra note 32. 
sample. Furthermore, it is not clear why socioeconomic composition per se should lead to higher incomes.

\section{IV}

\section{Social Science and the Choice of a Strategy}

The difficulty of using social science research to determine how different educational strategies can be used to affect the future life chances of low income and minority students is clear. While virtually all of the four hypotheses discussed above have some support, the results are ambiguous and inconclusive. Advocacy of any particular approach, therefore, is not based so much upon its general acceptance in the scientific community as it is upon the predilections of researchers and policy makers. The fact that they as well as the courts have not been neutral among competing ideas suggests that it is useful to explore the reasons that particular strategies are selected.

At the outset, one may very well ask how social science researchers can commit themselves to a particular hypothesis or approach on the basis of ambiguous, fragmented, and often contradictory findings. The answer, seemingly, is that researchers often have commitments based upon deeply ingrained social experiences that affect their understanding of how society functions. The natural consequence of these experiences encourages the social scientist to accept the evidence which reinforces his own experience and to be skeptical of that which does not. ${ }^{47}$ As Polanyi has noted: ${ }^{48}$

I start by rejecting the ideal of scientific detachment. In the exact sciences, this false ideal is perhaps harmless, for it is in fact disregarded there by scientists. But we shall see that it exercises a destructive influence in biology, psychology and sociology and has falsified our whole outlook far beyond the domain of science.

To a substantial degree the social scientist is himself a product of the very forces he wishes to study. Long before he has received his professional training he is exposed to such phenomena as class, race, family structure, money, prices, religion, industry, politics, work, the messages of the media on all of these subjects, and more. His perspective of the world is largely a cumulative result of his role as a child, student, sibling, husband, consumer, professor, rich man, black, woman, mother, and so on. All of these roles have defined the bound-

47. See generally P. Berger \& T. Luckman, The Social Construction of Realtty (1966); T. Kuhn, The Structure of Scientific Revolutions (1962); K. Mannheim, Ideology and Utopia (1936); R. Merton, Social Theory and Social Structure (1949); R. Merton, The Sociology of Science (1973); M. Polanyi, Personal Knowledge (1958); K. Popper, Objective Knowledge: An Evolutionary Approach (1972); Y. Elkana, Rationality and Scientific Change, 1972 (unpublished manuscript at Department of History and Philosophy of Science, Hebrew University, Jerusalem); Y. Elkana, The Theory and Practice of Cross-Cultural Contacts, 1972 (mimeograph at Hebrew University, Jerusalem).

48. M. Polanyi, supra note 47 , at vii. 
aries of experience which in turn mold his social reality. ${ }^{49}$ In a more specific sense, the social scientist who studies the effects of schooling on achievement has been socialized to a large degree by his own particular experiences during his education. His knowledge about the determinants of poverty is influenced by his own class origins and experiences. His image of political reality is conditioned by his own interactions with the political system and other institutions that inculcate political attitudes. Interacting with these influences is his professional training which emphasizes particular metaphysical and epistemological frameworks for viewing the world.

Moreover, since researchers are not randomly assigned to studies, the effects of the researcher's commitment and ideology on the interpretation of research findings is not a chance event. To the contrary, there is a self-selection of problems by researchers according to their predilections, as well as the selection by government and other decision makers, based upon the "outlook" of the researcher and the sponsoring agency. Social science investigators choose those problems that interest them and to which they feel they can contribute something of value. Of course, research support is also a prerequisite, but most social science analysts-particularly in the academic setting-have a choice of problems on which to focus. Public policy-oriented research has a substantive or topical component that may or may not be of interest to potential investigators. Such motives as a sincere wish of the individual to improve government decision-making are often strong factors in the choice of problems, but they also coincide with a deep personal involvement in the outcome of the study. That is, the researcher is likely to have relatively strong viewpoints about what proper policy should be in advance of his research.

The agencies that support research are just as likely to select a researcher on the basis of his values as on his "scientific" competence. As Paul Samuelson has remarked: $:^{50}$

The leaders of this world may seem to be led around through the nose by their economic advisers. But who is pulling and who is pushing? And note this: he who picks his doctor from an array of competing doctors is in a real sense his own doctor. The Prince often gets to hear what he wants to hear.

It would be inconceivable to think of the United States Commission on Civil Rights hiring a researcher for his neutrality on the desegregation issue. Indeed, we expect that government decision makers seek out those investigators who are sympathetic to the agency's own orientation.

Obviously, these phenomena dovetail very closely with the use of social science evidence in the courts. Legal proceedings are endeavors in advocacy, each side seeking that "evidence" which will support its own position. There is always some social science evidence on virtually any phenomenon, so one must

49. See P. BERGER \& T. LuCKMAN, supra note 47.

50. Samuelson, Economists and the History of Ideas, 52 A M. Econ. Rev. 1, 17 (1962). 
ask what types of evidence are likely to be drawn into the courts. I assert that the social science evidence which courts are likely to receive has the following attributes: (1) It tends to be based upon complex, statistical methodologies that are generally beyond the experience and the competence of the court to question. (2) It directly supports or refutes the matter under consideration. (3) It is based upon a theory which is credible and understandable to the court. (4) And, finally, it implies a remedy that is readily within the court's power and is politically feasible.

The first requirement evolves from the image that the layman has of science. "Good" social science is characterized by large data sets, complicated statistical methodologies, and an aura of technical competence. While the researcher has made many personal judgments with respect to his formulation of the problem-selection of a framework for the analysis, definition and measurement of variables, technique of data analysis and interpretation of results-all will tend to be obscured by what appears to be a strictly technical analysis. The greater the methodological sophistication, the more difficult it is to demystify the analysis and the more tempting it becomes to see "the emperor's new clothes." The bias in favor of sophisticated empirical studies also rules out the consideration of hypotheses that are not conducive to empirical evaluation.

The second requirement suggests that ambiguity in research findings will be shunned. Alternative interpretations of the results can obviously be dangerous to the advocate who uses the evidence to support his client's case. Thus, the social science research that is utilized must unequivocally support the particular objectives of the advocate. This tends to eliminate any opportunity for a thoughtful analysis of all of the competing hypotheses.

The third requirement, that the social science evidence presented to the court be based upon a credible hypothesis, is illustrated by the fact that while social science research in the Marxian tradition may be both extremely sophisticated and unambiguous, the theory upon which it is based may not be acceptable to those heavily indoctrinated with the capitalist viewpoint.

Another example: no evidence has been presented in either the desegregation or the school finance cases that argues in favor of the noncognitive worker characteristics hypothesis as an explanation of the effects of schools on the life attainments of children from low income and racial minority backgrounds. ${ }^{51}$ To the educated layman the cognitive skills theory is much more credible than the noncognitive one.

51. But of. Serrano v. Priest, Civil No. 938.254 (Cal. Super. C.. Apr. 10. 1974). In that case. conflicting evidence was introduced on the proper test to be applied in delermining the quality of education existing within a school district, defendants urging the "pupil-achicrement standard" while the plaintiffs urged a "school-district-offering standard." $I d$. at 52 . The controlling dispute did not focus on the relationship between noncognitive theories of education and life attainment. and much of the opinion was cast in terms of the skills and cognitive achievement hypothesis. Sue, 
Finally, the requirement that the social science evidence presented to the court implies a remedy that is both within the court's remedial powers and is politically feasible, is illustrated, for example, by the fact that given the present institutional framework, it is not possible for the court to interfere with family child-rearing for educational purposes. Yet studies have shown that such interventions will improve the life chances of students from low income families. ${ }^{52}$

In light of these principles it is understandable that the courts and other policy makers have focused primarily on the cognitive skills approach. Firstly, the research in this area, beginning with the Coleman Report"3 and the "Racial Isolation" report of The U. S. Commission on Civil Rights the following year,",4 has the aura of being methodologically sophisticated and empirical. Enormous data sets (about 650,000 students and 70,000 teachers comprise the Coleman Report data), sophisticated methodologies such as multiple regression analysis, and quantification of educational outcomes as reflected in test scores, create a strong image of valid scientific endeavor. Secondly, these studies purport to show unambiguously that socioeconomic and racial integration as well as certain school resources improve the test scores of low income and minority students. Thirdly, educated men tend to believe that cognitive test scores are important determinants of life chances because they are likely to attribute their own educational and occupational success to their relatively high levels of knowledge and skills rather than to "less rational" factors such as those related to family socioeconomic origins. Cognitive skills are an attractive basis for constructing the meritocracy. ${ }^{55}$ Finally, implementation of the desegrega-

e.g., id. at 89. By holding for the plaintiffs, however, the court accepted the testimony that "Standardized achievement tests . . a are not appropriate for measuring the degree of attainment of many of the educational goals of the State. .." They "do not measure for progress in the affective domain-a pupil's personality characteristics, interests and attitudes, interpersonal skills and socialization skills." Id. at $9 \mathrm{l}$. In concluding that standardized test scores are not determinative of the quality of an educational program, the court also adverted to the parties stipulation to the following:

That a child's self-concept can be improved by the educational process; that the educational process can reinforce a child's negative self-concept; that schools can, do, and should, play a role in providing a child with acceptable social values and behavior norms; that schools can, do, and should, play a role in equipping children with what it takes to get along in a technological society; that schools can, do, and should, play a role in making children better future citizens; that many components of a good education are not measured by pupil performance on achievement tests; that many aspects of a student's capabilities and progress are not measured by performance on achievement tests; and that the scope of skills measured by achievement tests is limited.

52. See, e.g., Bowles, supra note 14; Bowles, supra note 19; Hess, Shipman, \& Jackson, Early Experience and the Socialization of Cognitive Modes in Children, 36 Child Development 869 (1965); Olim. Hess. \& Shipman, Role of Mothers Language Styles in Mediating Their Pre-School Children's Cognitive Development, 75 School Rev. 414 (1967).

53. See J. Coleman, supra note 25.

54. See U.S. Commission on Civil Rights, supra note 30.

55. See R. Herrnstein, IQ in the Meritocracy (1973); M. Young, The Rise of the Meritocraci (1958); Bowles \& Gintis. supra note 35. 
tion and compensatory education strategies implied by the cognitive hypothesis are within the powers of the courts and educational decision makers.

\section{V}

\section{Effects of Social Science Evidence}

Thus far, it has been argued that the social sciences cannot produce conclusive results that would support a particular educational strategy for improving the life attainments of students from low income and minority families. Also, it has been asserted that the evidence that does enter the courts or policy arena is considered and utilized on the basis of factors other than its scientific "validity." What are the implications of these assertions for the evolution of public policy and the law?

There are three possible cases. The first is the happy one where the evidence presented is somehow the "best" that is available. In other words, the evidence is based upon the clearest attainable picture of the world and is unequivocally better than that which supports alternative hypotheses on the subject. It is not clear how this would happen but to the degree that it does occur, it can be viewed as advancing the wisdom of the legal system. The second case is a less benevolent one in which the social science evidence, while representing just one among competing views on the subject, nonetheless carries the day. To the degree that the results of the research are erroneous, the use of social science may be harmful.

But in many ways it is the third case that is most interesting. Here social science evidence is used to support both sides of a legal dispute. ${ }^{56}$ In educa-

56. In Hobson v. Hansen, 327 F. Supp. 844 (D.D.C. 1971), Judge J. Skelly Wright commented on the utilization of expert social science evidence in an adversary proceeding:

Plaintiffs' motion for an amended decree and for further enforcement has now been argued and reargued via a series of motions and written memoranda for one full year. During this time the unfortunate if inevitable tendency has been to lose sight of the disadvantaged young students on whose behalf this suit was first brought in an overgrown garden of numbers and charts and jargon like "standard deviation of the variable," statistical "significance," and "Pearson product moment correlations." The reports by the experts-one noted economist plus assistants for each side-are less helpful than they might have been for the simple reason that they do not begin from a common data base, disagree over crucial statistical assumptions, and reach different conclusions. Having hired their respective experts, the lawyers in this case had a basic responsibility, which they have not completely met, to put the hard core statistical demonstrations into language which serious and concerned laymen could, with effort, understand. Moreover, the studies by both experts are tainted by a vice well known in the statistical trade-data shopping and scanning to reach a preconceived result; and the court has had to reject parts of both reports as unreliable because biased. Lest like a latter day version of Janndyce $v$. Jarndyce this litigation itself should consume the capital of the children in whose behalf it was brought, the court has been forced back to its own common sense approach to a problem which, though admittedly complex, has certainly been made more obscure than was necessary. The conclusion I reach is based upon burden of proof, and upon straightforward moral and constitutional arithmetic.

Id. at 859 . 
tional finance litigation, the constitutionality of state school finance systems was challenged on the ground that they provided lower quality education for children in low property wealth districts than for those in more affluent districts. The defense relied upon social science research which, they asserted, indicated no relationship between the level of expenditures and the quality of an education program. The defense arguments were buttressed by the Coleman Report ${ }^{57}$ and other research, ${ }^{58}$ tending to show that there was little or no causative effect between educational expenditures and other measures of school quality and student achievement. The plaintiffs countered with witnesses and research that disputed the methodologies and data employed in the studies cited by the defense, and which indicated a correlation between increases in educational resources and improved pupil achievement. ${ }^{59}$ In some cases the plaintiffs won the argument; ${ }^{60}$ in others, the courts were unpersuaded. ${ }^{61}$

Even where both sides draw upon social science evidence and the court decides between the two competing presentations, there is a possibility that use of such evidence will tend to redefine the issue itself. Presentation of evidence on the relationship between educational expenditures and cognitive achievement implicitly narrows the context within which the effects of unequal expenditure patterns will be considered. While the two sides to this debate disagree on the effect of school resources, both have accepted the view that standardized achievement scores are the appropriate focus for exploring educational outcomes. Since courts and policy makers generally find it easier to understand a point of agreement than of contention, such points of accord have more influence on the assimilation of the policy implications of research than the conclusions of the research itself. Thus, much of the legal debate surrounding the challenge to present methods of financing education does not address the basic unfairness reflected by state arrangements to spend more on the education of children in rich districts than in poor ones. Rather, the prima facie inequities are ignored as the courts are tortured with the convoluted arguments provided by social scientists about whether money makes a difference for "poor kids." ${ }^{2}$ It is unfortunate that the issue has now become framed in

57. See J. Coleman, supra note 25.

58. See generally, Jencks; ON EQUality of Educational. Opportunity, supra note 31.

59. See, e.g., J. Guthrie, G. Kleindorfer, H. Levin, \& R. Stout, Schools and Inequality (1971); E. Hanushek. Education and Race (1972); Bowles \& Levin, supra note 31 ; Hanushek \& Kain, supra note 31 .

60. See, e.g., Serrano v. Priest, Civil No. 938,254 (Cal. Super. Ct., Apr. 10, 1974); Robinson v. Cahill, 62 N.J. 473, 303 A.2d 273 (1973).

61. See, e.g., Jensen v. State Bd. of Tax Comm'rs, Civil No. 24,474 (Ind. Cir. Ct., Jan. 15, 1973).

62. It seems inconceivable that prior to the Coleman Report a state would defend its arrangements to spend more money for the education of children in wealthy districts than in poor ones by arguing that dollars do not affect educational outcomes. I believe that this assertion would seem incredulous to a court. Common sense suggests that if higher expenditures make a difference for children in wealthy districts, they also make a difference for pupils in poorer districts. At the least, a court should question why a state sanctions such high expenditures in wealthy districts if such 
terms of whether additional expenditures for children in poor school districts will raise their test scores. ${ }^{63}$

A second example of the tendency of a tacit consensus among litigants having a greater influence on policy formation than the actual research results, is the controversy over the effects of school desegregation. Until the mid1960 's, the case for racial desegregation was one that was based largely upon the type of society one envisioned. ${ }^{64}$ For those who equated a fair society with the absence of racial separation, segregation of schools was contradictory. For those who defined a fair society in other ways, racial isolation in the educational system was of little consequence. The argument was primarily a moral one, dealing with normative visions of the world. ${ }^{65}$

With the advent of the Coleman Report and the 1967 Report of the U. S. Commission on Civil Rights, Racial Isolation in the Public Schools, a new dimension was added. These studies attempted to demonstrate that segregated school environments retarded the test scores of black children and other students from lower socioeconomic backgrounds. By 1972, serious questions were being raised about the validity of the earlier findings. Reanalysis of the Coleman data did not support the hypothesis that the test scores of black students were a function of the racial composition of the schools. ${ }^{66}$ A subsequent analysis of several longitudinal studies of the effects of busing argued that the data do not support the conclusion that racial integration of schools in itself will improve the achievement levels of racial minorities and that there is at least some evidence that harmful changes in attitudes take place. ${ }^{67}$

The results of this study were shocking ${ }^{68}$ due to the fact that heretofore there seemingly had been one point of agreement in the social science studies on desegregation-that "[i]ntegrated education will enhance the academic achievement of minority groups, and thereby close (or at least substantially reduce) the achievement gap." 69 Despite the very contradictory literature on school desegregation, the case for desegregation was seen as hinging primarily on whether it improves the achievement test scores of minority students.

resources are "wasted." $C f$. Hobson v. Hansen, 327 F. Supp. 844 (1971), where the court stated that the defendants "cannot be allowed in one breath to justify budget requests to the Congress and to the District of Columbia City Council by stressing the connection between longevity and quality. teaching, and then in the next breath to disavow any such connection before the court." Id. at 855 .

63. See Carrington, Financing the American Dream: Equality and School Taxes, 73 Colcu. L. REv. 1227 (1973).

64. Ser generally Clark. Social Policy. Power, and Sorial Science Research. 43 Harv. Ed. Rev. 77 (1973).

65. Compare Cahn. Jurisprudence. 30 N.Y.U.L. Rev. 150 (1955), with Clark. The Desegregation Case' Criticism of the Social Scientists Role. 5 Vili.. L. REv. 224 (1960)

66. So Cohen. Pettigrew, \& Riley, supra note 31. al 439-50, 356.

67. Armor. supra note 31 .

68. The critics moved in quickly w question the criteria, statistical procedures. choice of studies reviewed, and other aspects of the Armor analysis. See Pelligrew. Lseem. Normand. \& Smith. supra note 30. The reply to this criticism also quickly followed. See Armor. supra note 23.

69. Armor, supra note 23. 
Rather than considering what kind of educational policy regarding school racial patterns is consistent with our democratic ideals, the issue seems to be whether or not blacks and other minorities gain a few more points on a vocabulary or reading test. This standard is far removed from the declaration of the Supreme Court of 1954 that the separation of black children "because of their race generates a feeling of inferiority as to their status in the community that may affect their hearts and minds in a way unlikely ever to be undone." 70 At this stage, the issue has thus been cast in terms of the achievement scores of blacks rather than in terms of the larger moral and human dilemmas raised by segregated public institutions. There is little doubt that the research agenda has framed the issue.

\section{Conclusion}

What is the proper role of social science in charting educational policy for improving the life chances of low income and minority students? The answer to that question is not clear. The question of the relationship between educational influences and actual adult status addresses a very complicated area of social and individual behavior. In particular, little is known about the effects of different school environments on human behavior, about underlying theories of human productivity and its determinants in a particular social setting, about the myriad of other influences that can intervene between the educational strategy and the adult outcomes many years hence, and about the appropriate measurements of even those factors that do seem relevant. Further, the fact that experimentation as an empirical investigating tool is politically and practically infeasible limits severely our ability to uncover the true relationships.

Some observers may react to these conclusions by suggesting the social science evidence in these complicated areas is likely to be so misleading and value-laden that we ought to ignore it. ${ }^{71}$ In contrast, some technocrats will argue that the case against the ability of social science to validate the relationships between education and life chances has been overstated and that rapid scientific advances in research methodology will even nullify those anomalies which have arisen. Both of these views assume that the social sciences must play a deterministic role in contributing to policy or that they can play no role at all. Yet, it may be the heuristic aspects of social science research which are most useful.

Alice Rivlin has suggested that we acknowledge the development of a "forensic social science," rather than pretending "to be part of the tradition of balanced, objective social science in which the scholar hides (or claims to hide)

70. Brown v. Board of Fduc., 347 U.S. 483,494 (1954).

71. In Rodriguez Justice Powell noted that in view of the division of opinion anong "scholars and educational experts. . [on] the extent to which there is a demonstrable correlation between educational expenditures and the quality of education," the judiciary should refrain from deciding the issue. 411 U.S. al $42-43$. Set also id. at 11.86. 
his personal biases, and attempts to present all the evidence on both sides of a set of questions so that the reader may judge for himself." ${ }^{22}$ Using the notion of a forensic social science for addressing policy issues, ${ }^{73}$

scholars or teams of scholars take on the task of writing briefs for or against particular policy positions. They state what the position is and bring together all the evidence that supports their side of the argument, leaving to the brief writers of the other side the job of picking apart the case that has been presented and detailing the counter evidence.

The problem with such an approach is that it assumes that all of the sides will be fairly represented. But adversary proceedings normally are based upon only two conflicting points of view ${ }^{74}$ Moreover, the fact that the epistemology of the social sciences itself limits the analysis to a specific set of hypotheses (particularly ones that have readily identifiable empirical consequences) suggests that the issue might be framed in an erroneous manner. Of course, this type of bias can be avoided by permitting non-social scientists to enter the forum to present their views and argue their evidence. It is not clear what criteria would be used to select such witnesses nor is it obvious how one could determine how many points of view should be permitted. It is also not clear that the courts would attach great weight to "non-scientific" presentations. Finally, the court lacks expertise in selecting among alternative presentations that are grounded in complex statistical procedures and highly technical language. ${ }^{75}$ Of course, the court could hire its own experts for examining and interpreting the evidence, but what guarantees the objectivity of the "wise men" who advise the court? 76

Social science research can best be used to frame the issues and their consequences rather than to obtain conclusive evidence on what is right and what is to be done. This approach requires a recognition that while many aspects of the world cannot be quantified or analyzed in a social science setting, such factors should be considered along with the results of social science research. ${ }^{77}$ It is not clear that utilization of social science research in this manner is consistent with an adversary framework. Further, if social science findings increasingly are used to create what appear to be technical issues out of essentially moral dilemmas, this presents a potential social danger. The apparently increasing reliance of the courts on social science evidence suggests that intensive debate on these issues should be given high priority.

72. Rivlin, Forensic Social Science, 43 Harv. Ed. REv. 25 (1973).

73. Id.

74. While in most school litigation expert testimony is offered by both parties to the dispute, see, e.g., Serrano v. Priest, Civil No. 938,254 (Cal. Super. Ct., Apr. 10, 1974); in Robinson v. Cahill, 118 N.J. Super. 223, 287 A.2d 187 (1972), only the plaintiffs introduced expert witnesses on the relationship between expenditures and achievement.

75. See note 56 supra.

76. And even if the court's own expert is "objective," by what criteria, for example, is he to choose between two competing economic theories?

77. See Address by D. Campbell, supra note 4 . 